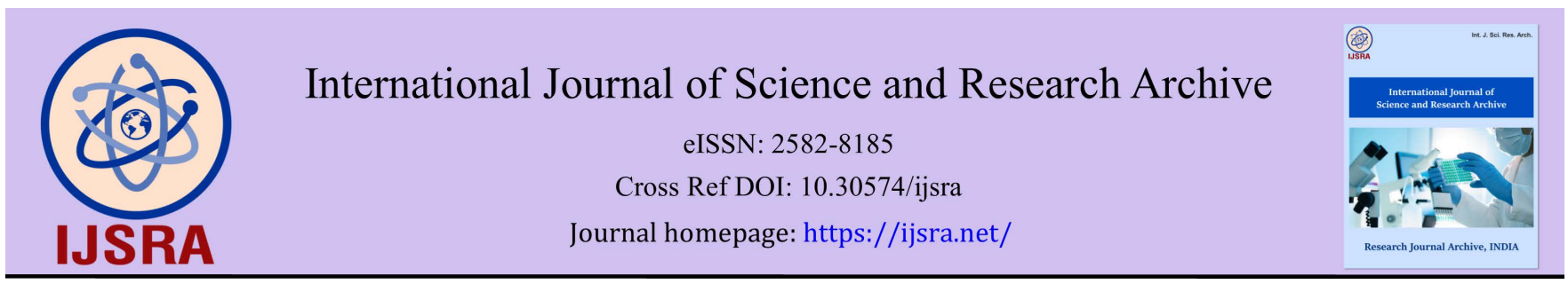

(RESEARCH ARTiClE)

\title{
Technical performance evaluation of a double row tractor operated yam minisett planter
}

\author{
Albert K. Arkoh 1, 2, ${ }^{*}$ Emmanuel Y.H Bobobee ${ }^{2}$ and Ahmad Addo ${ }^{2}$ \\ ${ }^{1}$ Department of Automobile and Refrigeration, Takoradi Technical University (TTU), Takoradi, Ghana. \\ 2 Department of Agricultural Engineering and Biosystems, Kwame Nkrumah University of Science and Technology \\ (KNUST), Kumasi, Ghana.
}

International Journal of Science and Research Archive, 2021, 04(01), 001-011

Publication history: Received on 17 July 2021; revised on 20 September 2021; accepted on 22 September 2021

Article DOI: https://doi.org/10.30574/ijsra.2021.4.1.0123

\begin{abstract}
Uniformity in plant spacing, evenness of dropping, planter capacity and among others has been identified as constraints facing planter performance. The main objective of the study was to evaluate the technical performance of the developed double row yam minisett (DRYM) planter. Category (I) tractor 50 hp was used to carry out field trials to determine the metering efficiency, effective field capacity, evenness of dropping, fuel consumption and wheel slippage. Three (3) yam varieties (pona, dente and CRI afase biri) of the average weight of $50 \mathrm{~g}$ with moisture content (82\%) were used for the test. Multivariate and (ANOVA) statistical method was used for analyzing the similarities among the tractor speed using OriginPro 2018 software. Metering efficiency (80.4\%), effective field capacity (3.84 h/ha), field efficiency (66.6\%), evenness of dropping (81.00\%), and wheel slip (3.39\%) were recorded. The use of developed planter will be expected to reduce human drudgery and also timeliness improvement. The study concluded that planter should be used on relatively flat (ploughed-harrowed) land to avoid wheel not touching the ground.
\end{abstract}

Keywords: Metering mechanism; Planter; Technical performance; Yam minisett

\section{Introduction}

The traditional method of planting is painful and time consuming according to [1,2]. Higher output and productivity are the two major contributions in farm mechanization. Planter plays a role in mechanization. The output in yam minisett planting using a double row yam minisett (DRYM) planter depend on relations among the number of mechanisms. According to Steele et al. [3], machine performance and capability to work fast with less demand for labour rest on relationships between the technical qualities of the machine. The primary aim of the DRYM planter was to integrate its functional requirement (planting) such as creating furrow, picking and dropping sett into the furrow, covering, and firming. These function procedures are supposed to be achieved by planter major parts such as furrow opener, ridger bottom, metering mechanisms, hopper and among others to achieve planter functional requirement. According to Pavek and Thornton [4], planter function improvement leads to high productivity and ease harvesting. Seed spacing uniformity according to Seyedbagheri [5] has a significant role to evaluate planter performance. Also, to increase yield, uniformity of plant spacing is necessary [6]. Increasing or decreasing plant stand by $10 \%$ leads to lessening yield from 2 to $12 \%$ [7]. Physical properties are powerful features that impact the capability of agricultural equipment [8]. Because of that, [9] evaluated the planter metering mechanism through the shape of a potato, belt speeds, and the number of cups. Again, $[9,10]$, concluded that ground wheel speed, different seed sizes, and shapes affect the plant spacing. Planter specifications and functional requirements affect crop yield; therefore, there is a great need to evaluate the performance of developed double row yam minisett (DRYM) planter. Therefore, the main objective of the study was to evaluate the field performance of the developed DRYM planter. The planter is hoped to perform well in different yam varieties and

\footnotetext{
${ }^{*}$ Corresponding author: Albert K. Arkoh

Department of Automobile and Refrigeration, Takoradi Technical University (TTU), Takoradi, Ghana.

Copyright (C) 2021 Author(s) retain the copyright of this article. This article is published under the terms of the Creative Commons Attribution Liscense 4.0.
} 
environment so that it can be adopt for different yam variety to increase yam productivity in Ghana and neighbouring countries.

\section{Material and methods}

\subsection{Study site}

The study site was Kwame Nkrumah University of Science and Technology (KNUST) Research Farm (Anwomaso) arable farm located $\left(6^{0} 41^{\prime} 56.75^{\prime} \mathrm{N}, 1^{0} 31^{\prime} 25.85^{\prime} \mathrm{W}\right)$, in the forest zone of the Ashanti Region. Figure 1 shows a map of Ghana at the study site. Anwomaso experiences two rainy seasons (bi-modal rainfall), the main season starts from March to July and minor from September to November [12]. The classification of soil at the experimental site was sandy loam and soils were predominantly Forest Ochrosols, while mean annual rainfall, relative humidity was $1200 \mathrm{~mm}$ and $72.8 \%$ respectively. Temperature also ranges from 20 to $32^{\circ} \mathrm{C}$ [12].

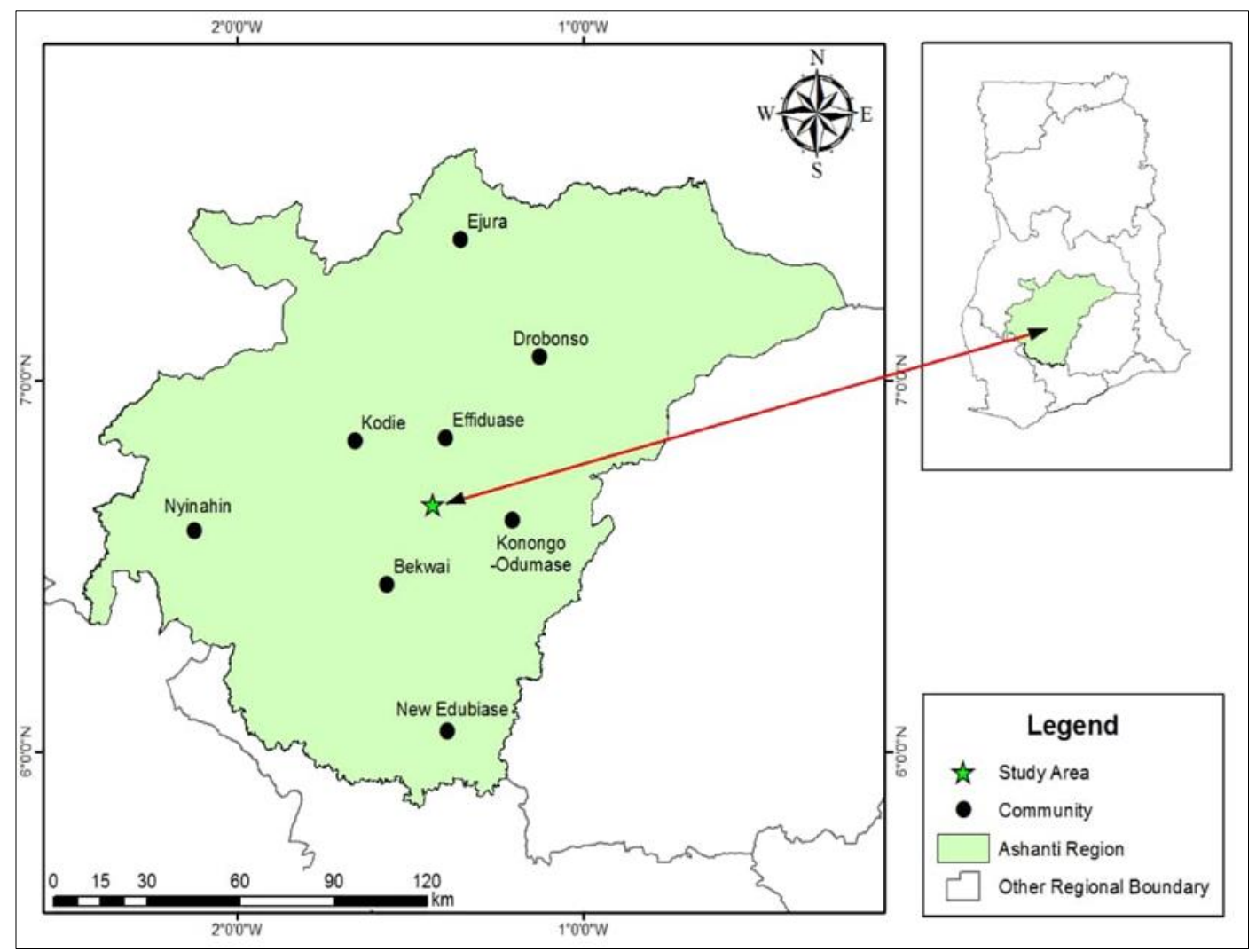

Figure 1 Map showing the study site

\subsection{Soil physical properties}

Soil moisture content (Mc), bulk density (bd) and penetration resistance (cone index) were measured in the field before ploughing (BP), after ploughing and harrowed ( $\mathrm{AH}$ ) and at planting (Apt). These properties were determined because they are the greatest essential to soil-implement tool and tuber yield as well. Five replicates of soil samples were collected randomly for measuring the soil physical properties upto $35 \mathrm{~cm}$ layer at $5 \mathrm{~cm}$ intervals using a method by $[13,14]$. Penetrometer for measuring soil penetration resistance consists of a handle, dial gauge graduated vertical rod with $2.0 \mathrm{~cm}^{2}$ base area. Readings $0-35 \mathrm{~cm}$ from the rod was recorded against corresponding readings from the dial gauge.

\subsubsection{Moisture content}

Moisture content $(M C)$ was determined using Equation 1. 


$$
M c=\frac{\text { Soil wet weight-soil oven-dry weight }}{\text { Soil oven-dry weight }} \times 100 \%
$$

\subsubsection{Bulk density measurement}

Soil bulk density was determined using Equation 2.

$$
\text { Oven-dried bulk density }(\rho)=\frac{M}{\pi r^{2} l}
$$

Where $M$ is = mass of the dried sample $r=$ radius (internal) of core samplers and $l=$ length of the cylindrical sampler.

\subsection{Field performance evaluation}

Planter ready for field trials was shown in Figure 2. Field evaluation was conducted by adopting methods by $[15,16,17]$.The evaluation was done at the KNUST research field (Anwomaso). Plot size of $50 \mathrm{~m}$ by $15 \mathrm{~m}$ was ploughed and harrowed using a disc plough and disc harrow respectively to produce finer soil tilt. The average size of minisett 50 g acquired from Crop and Scientific Research (CSR), Kumasi, Ghana with moisture content 82\% was used for field trials. Cabrio tractor $50 \mathrm{hp}$, category I, Four-Wheel Drive (4WD) was used for the trials. Before planting operations, necessary adjustments were made, and weeds were cleared to the plainest minimum as these could block the coverer of the planter and expose minisett to damage as well as reducing draught on the tractor

Planter performance evaluation was carried out to determine parameters such as planter operating speed, operating time, planting rate, depth of soil cover, metering efficiency, field efficiency, theoretical capacity $(T c)$, field capacity $(F c)$, percentage sett damage $(S d)$, evenness of planting $(E d)$, wheel slip $(W s)$ and fuel consumption. Planter performance evaluation measurement under real farm conditions and how evaluation parameters behave in soils with different physical properties were determined.

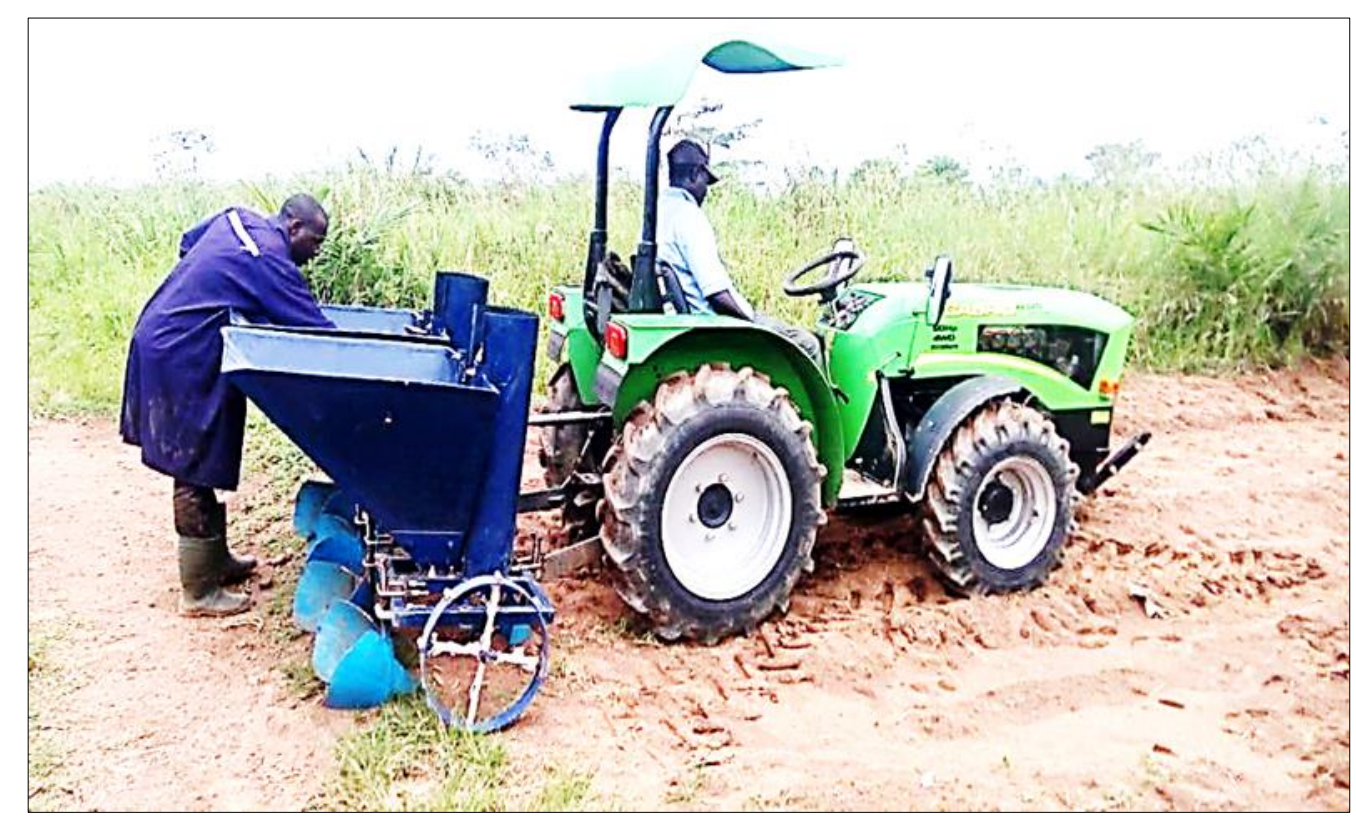

Figure 2 Planter mounted to tractor ready for planting

\subsection{Measurement of planting depth and rate}

Measurement of planting depth was done using a graduated metal ruler. Fifty (50) different plants were randomly sampled and uprooted after 60 days of planting. The measurement from the bottom of the plant to the top of the soil profile was measured to determine the planting depth as adopted from Smith, [18]. About $5 \mathrm{~cm}$ topsoil was assumed to be eroded after 45 days after planting and the same $5 \mathrm{~cm}$ value was added to each measured value. The rate of planting was determined by dividing the number of plants planted by total planting time Awulu et al. (2013). 


\subsection{Mechanised planting capacity}

Planting capacity was determined using Equation 3 adopted from Awulu et al. [17]. The field capacity was measured during mechanical planting by recording the total time used for planting a given number of plants or areas of the field. Trials were completed without stopping unless necessary corrections or breakdowns.

$$
T=\frac{n \times 36}{10000 \times t}
$$

where, $T=$ Total planting capacity (sett/h), $t=$ Total time spent in planting (seconds), $n=$ Number of minisett planted.

\subsection{Theoretical field capacity}

Theoretical field capacity (TC) was determined using Equation 4 [16], 36 is speed convention factor.

$$
\text { Theoretical capacity }=\frac{\text { Mean working width } \times \text { mean tractor speed } \times 36}{10000}
$$

\subsection{Effective field efficiency}

The association between effective field capacity and theoretical field capacity is planter field efficiency [16]. Equation 5 presents how field efficiency was determined.

$$
\text { Planter field efficiency }=\frac{\text { Planter effective field capacity }}{\text { Planter theoretical field capacity }} \times 100
$$

\subsection{Metering efficiency}

The measurement of the metering efficiency $(M e)$ mechanism was obtained by recording the number of setts metered $(S d)$ and compered with number of setts expected $(S e)$. Equation 6 was adopted from [16,17].

$$
M e=\frac{S d}{S e} \times 100 \%
$$

\subsection{Evenness of dropping}

Evenness of dropping $(E d)$ was determined by comparing average actual metered $(A m)$ space with expected dropping (ed) space using Equation 7 [16].

$$
E d=\frac{A m}{e d} \times 100
$$

\subsection{Percentage sett damage}

The percentage sett damage $(S D)$ was determined by the ratio of the initial and final weight of the sett. This test was done on the hard surface after the furrow opener and ridger bottom removed [17].

\subsection{Wheel slip}

The arrangement of ranging poles for determination of wheel slip during field trials were adopted from Amponsah et al. (2014). Wheel slip was determined using Equation 8 [12].

Wheel Slip $=1-\frac{B}{A} X 100 \%$

where, $A=$ mean distance under no-load, $\mathrm{B}=$ mean distance under load

\subsection{Fuel consumption measurement}

Amponsah et al. [12] directly measured fuel consumption of the tractor for field operation. The quantity of fuel needed by the tractor was determined by filling the fuel tank to the brim before and after each trial. Quantity of fuel in liters required to refill the tank was recorded as the fuel consumed for the operated area. 


\subsection{Experimental design and data analysis}

The experimental design was a randomized complete block (RCBD) with three (3) replications. Planter plants two rows at a time. A total of 5 passes planted 500 treatment combinations. Treatments were yam varieties (Pona, Dente, and CRI Afase biri). Measurements were made at the tractor forward speeds of 2, 3, 4, and $5 \mathrm{~km} / \mathrm{h}$ for 50 m distance traveled. The treatment combination was purposively assigned to an experimental plot due the nature of planter design.

Data obtained from the planting trials were statistically analysed. Descriptive statistics and analysis of variance (ANOVA) were done using GenStat software (VSN International, 2011) and OriginPro 2018 software. Means were obtained using the least significant difference (LSD). Statistical significance was carried out at $p \leq 0.05$. Tukey and Fisher's approach was used to determine any differences in treatment measured.

\section{Results and discussion}

\subsection{Soil physical property}

Soil moisture content, bulk density, and penetration resistance before ploughing (BP), after harrowing (AH) and at planting (Apt) were presented in Figure 3. The average moisture content of BP, AH, and Apt were 8.36\%, 10.10\%, and $15.70 \%$ (d.b), respectively. The moisture content of BP decreased with increasing soil depth, but the trend was opposite for AH and Apt. Increasing moisture content AH and Apt with increasing soil depth might have been caused by heavy downpour after ploughing. Tasks occurring at different days could also play a role in the moisture content variation with activities at BP, AH, and Apt. Decreasing moisture content with increasing depth at BP confirms a report by [12,19] that moisture content decreased with increasing soil depth.

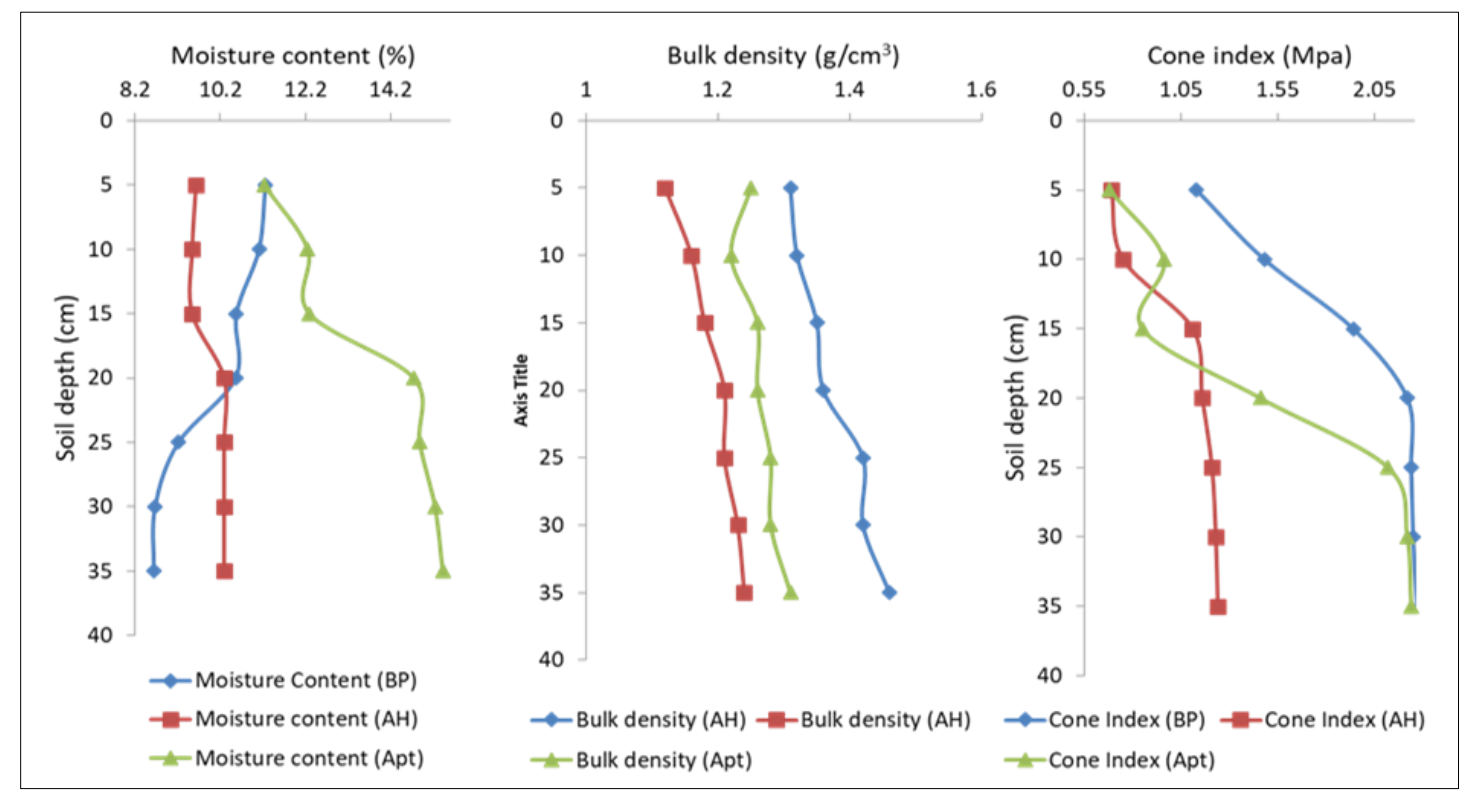

Figure 2 Mean Moisture Content against Soil Depth

The average soil bulk density of BP, AH, and Apt for the trial site were $1.43,1.36$ and $1.31 \mathrm{~g} / \mathrm{cm}^{3}$, respectively. The bulk densities increase at an increasing soil depth of 0 to $35 \mathrm{~cm}$. Soil bulk density generally increased with increasing soil depth. It was observed that, bulk density before ploughing recorded the highest value followed by at planting and after ploughing. Difference in bulk densities could attribute to the fact that the process of ploughing breaks the soil into smaller clods to be easily compacted when the tractor wheels pass over the soil during the ploughing process. Also, soil samples were taken at different days after ploughing when the soil had attained some degree of compaction. USDA, [20] reported that compacted soil layers have high bulk densities. The general trend shows an increasing soil bulk density with increasing soil depth.

Penetration resistance increased with soil depth from 0 to $35 \mathrm{~cm}$ before and after ploughing. The average penetration resistance of $\mathrm{BP}, \mathrm{AH}$, and Apt were 1.93, 1.05, and $1.50 \mathrm{MPa}$, respectively. The result displays general soil strength with 
increasing soil depth for all land preparation stages. The cone penetrations before ploughing and at planting were higher than that after ploughing. This suggest that ploughing the soil lessens the penetration resistance as observed from the graph. The trend confirms a report by $[12,19]$ that penetration resistance increases with soil depth.

\subsection{Planter field performance evaluation}

The mean planting depth measured was $16.4 \mathrm{~cm}$. This value falls within a planting depth of 12 to $25 \mathrm{~cm}$ recommended by Awulu et al. [12]. There was significant difference $(\mathrm{p} \leq 0.05)$ in metering efficiency of $81.17 \%$ recorded for pona while the least of $80.22 \%$ was recorded for CRI afase biri (Table 1). Physical properties of yam variety could play a role in differences in metering efficiency base on the fact that shape of the sett disturbs the picking and falling from the cups. This was in agreement with Buitenwerf et al. [9] that dropping of potato is affected by the shape of the potato.

Table 1 presents the means of evaluated parameters of the planter at varying planting speed. The highest planter capacity of $3.7 \mathrm{~h} / \mathrm{ha}$ was recorded at $5 \mathrm{~km} / \mathrm{h}$ while the least of $4.16 \mathrm{~h} / \mathrm{ha}$ was recorded at planter working speed of 2 $\mathrm{km} / \mathrm{h}$. There was a significant difference $(\mathrm{p} \leq 0.05)$ in planter capacity. The planter capacity increased with increasing planter speed. The results were in agreement with Awulu et al. [17]. Increasing capacity with speed implies that larger farmland could be planted within a shorter time. The result was in agreement with [21,22] recorded a capacities of 3.57 and $5.0 \mathrm{~h} / \mathrm{ha}$ at planting speeds of 2.5 and $2.7 \mathrm{~km} / \mathrm{h}$, respectively. The recorded capacity was below capacity of 0.66 $\mathrm{h} / \mathrm{ha}$ at a speed of $2.8 \mathrm{~km} / \mathrm{h}$ for the developed metering device by Awulu et al. [17]. The different metering design employed and of soil conditions could contribute to the differences in the planter field capacity.

Table 1 Mean metering efficiency (ME), evenness of dropping ( $E D)$, planter capacity $(P C)$, and fuel consumed $(F C)$ and wheel slippage $(W s)$ of Planter influence by planting speed

\begin{tabular}{|c|c|c|c|c|c|c|c|}
\hline \multicolumn{8}{|c|}{ Evaluation parameters } \\
\hline $\begin{array}{c}\text { Planting } \\
\text { speed } \\
\text { km/h }\end{array}$ & $\begin{array}{c}\text { Planting } \\
\text { Capacity } \\
\text { (h/ha) }\end{array}$ & $\begin{array}{c}\text { Evenness of } \\
\text { dropping } \\
(\%)\end{array}$ & $\begin{array}{c}\text { Metering } \\
\text { efficiency } \\
(\%)\end{array}$ & $\begin{array}{c}\text { Percentage } \\
\text { damage } \\
(\%)\end{array}$ & $\begin{array}{c}\text { Theoretical } \\
\text { Capacity } \\
\text { (h/ha) }\end{array}$ & $\begin{array}{c}\text { Fuel } \\
\text { consumpt } \\
\text { ion(l/ha) }\end{array}$ & $\begin{array}{c}\text { Wheel } \\
\text { slippage } \\
\text { (\%) }\end{array}$ \\
\hline 2 & $4.03 \mathrm{a}$ & $90.47 \mathrm{a}$ & $82.19 \mathrm{a}$ & $0.01_{\mathrm{a}}$ & 2.63 & $8.88 \mathrm{a}$ & $2.31_{a}$ \\
\hline 3 & $3.90_{b}$ & $87.11_{b}$ & $82.19 \mathrm{a}$ & $0.11_{b}$ & 2.63 & $9.20_{b}$ & $2.33_{b}$ \\
\hline 4 & $3.78_{c}$ & $81.31_{\mathrm{c}}$ & $78.48 b$ & $0.20_{\mathrm{b}}$ & 2.63 & $9.32_{c}$ & $4.20_{\mathrm{b}}$ \\
\hline 5 & $3.67_{d}$ & $89.37 \mathrm{a}$ & $80.59 \mathrm{c}$ & $0.90_{c}$ & 2.50 & $9.62 c$ & $4.74 c$ \\
\hline LSD & 0.008 & 1.311 & 1.252 & 0.124 & ns & 0.301 & 0.481 \\
\hline
\end{tabular}

\subsection{Field efficiency and evenness of dropping}

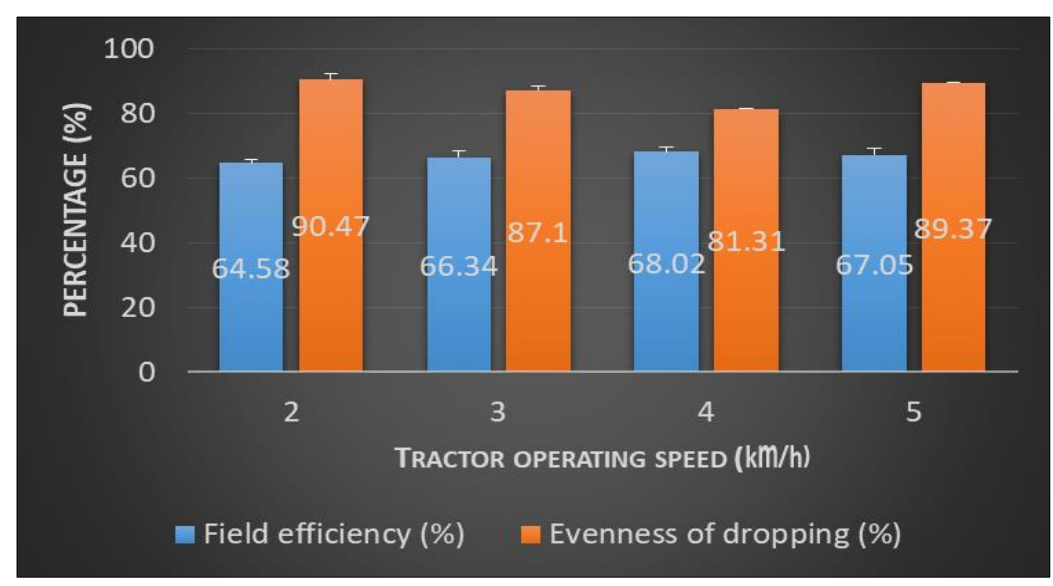

Figure 4 Tractor speed on-field efficiency and evenness of dropping 
Figure 4 shows the mean-field efficiency and evenness of dropping at varying planting speed. The highest field efficiency of $68.03 \%$ was at planting forward speed of $4 \mathrm{~km} / \mathrm{h}$ and the least field efficiency of $64.58 \%$ at a speed of $2 \mathrm{~km} / \mathrm{h}$. There were significant differences at $(\mathrm{P} \leq 0.05)$ in efficiency and positively correlated with tractor forward speed $(\mathrm{r}=0.899)$ as shown in Table 2. The planter metering ability to control the rate of skipping could played a role in higher efficiency. The recorded efficiency was within the range of 11.00 to $71.86 \%$ obtained by $[15,17]$.

The highest significant difference ( $\mathrm{p}>0.05)$ in the evenness of dropping of $90.47 \%$ was at a planter operating speed of $2 \mathrm{~km} / \mathrm{h}$ while the least of $81.31 \%$ occurred at $4 \mathrm{~km} / \mathrm{h}$. Evenness of dropping was a negative correlation with wheel slip and tractor forward speed; $(r=-0.279)$, and $(r=-0.329)$, respectively. The trend shows that evenness of dropping increased with decreasing planter forward speed. Skips during picking of minisett could contribute to the better evenness of dropping at planter reduced speed. The design made provision for adjusting the number of setts metered at a time by using a different set of cup-chain.

Table 2 Correlation matrix and Analysis Variance on tractor speed, metering efficiency (ME), evenness of dropping (ED), planter capacity (PC), and fuel consumed (FC) and wheel slippage (WS)

\begin{tabular}{|c|c|c|c|c|c|c|c|c|c|c|c|c|c|}
\hline \multicolumn{14}{|c|}{ Pearson Correlations and Analysis of variance } \\
\hline & & Speed & ME & ED & PD & PC & TC & FC & WS & BD & MC & CI & Pd \\
\hline \multirow[t]{2}{*}{ Speed } & PCor & 1 & & & & & & & & & & & \\
\hline & P-val & - & & & & & & & & & & & \\
\hline \multirow[t]{2}{*}{ ME } & PCor & -0.547 & 1 & & & & & & & & & & \\
\hline & P-val & 0.012 & - & & & & & & & & & & \\
\hline \multirow[t]{2}{*}{ ED } & PCor & -0.279 & 0.788 & 1 & & & & & & & & & \\
\hline & P-val & 0.233 & 0.000 & - & & & & & & & & & \\
\hline \multirow[t]{2}{*}{ PD } & PCor & 0.862 & -0.226 & 0.194 & 1 & & & & & & & & \\
\hline & P-val & 0.000 & 0.336 & 0.410 & - & & & & & & & & \\
\hline \multirow[t]{2}{*}{ PC } & PCor & 0.852 & -0.429 & -0.229 & 0.685 & 1 & & & & & & & \\
\hline & P-val & 0.000 & 0.058 & 0.330 & 0.000 & - & & & & & & & \\
\hline \multirow[t]{2}{*}{$\mathrm{TC}$} & PCor & 0.644 & -0.196 & 0.149 & 0.723 & 0.646 & 1 & & & & & & \\
\hline & P-val & 0.002 & 0.405 & 0.528 & 0.000 & 0.002 & - & & & & & & \\
\hline \multirow[t]{2}{*}{ FC } & PCor & 0.780 & -0.392 & -0.145 & 0.667 & 0.597 & 0.504 & 1 & & & & & \\
\hline & P-val & 0.000 & 0.086 & 0.541 & 0.001 & 0.005 & 0.023 & - & & & & & \\
\hline \multirow[t]{2}{*}{ WS } & PCor & 0.899 & -0.661 & -0.329 & 0.785 & 0.763 & 0.544 & 0.603 & 1 & & & & \\
\hline & P-val & 0.006 & 0.001 & 0.156 & 0.000 & 0.000 & 0.013 & 0.004 & - & & & & \\
\hline \multirow[t]{2}{*}{$\mathrm{BD}$} & PCor & 0.925 & -0.382 & 0.044 & 0.963 & 0.790 & 0.726 & 0.716 & 0.716 & 1 & & & \\
\hline & P-val & 0.004 & 0.095 & 0.853 & 0.000 & 0.000 & 0.000 & 0.000 & 0.000 & - & & & \\
\hline \multirow[t]{2}{*}{ MC } & PCor & 0.894 & -0.255 & 0.160 & 0.982 & 0.763 & 0.742 & 0.714 & 0.714 & 0.985 & 1 & & \\
\hline & P-val & 0.000 & 0.277 & 0.499 & 0.000 & 0.000 & 0.000 & 0.000 & 0.000 & 0.000 & - & & \\
\hline \multirow[t]{2}{*}{ CI } & PCor & 0.879 & -0.159 & 0.163 & 0.954 & 0.750 & 0.719 & 0.731 & 0.731 & 0.923 & 0.969 & 1 & \\
\hline & P-val & 0.000 & 0.501 & 0.490 & 0.000 & 0.000 & 0.000 & 0.000 & 0.000 & 0.000 & 0.000 & - & \\
\hline \multirow[t]{2}{*}{$\mathrm{Pd}$} & PCor & -0.066 & -0.079 & -0.101 & -0.100 & -0.020 & 0.084 & 0.078 & 0.078 & -0.087 & -0.118 & -0.146 & 1 \\
\hline & P-val & 0.780 & 0.739 & 0.669 & 0.674 & 0.932 & 0.722 & 0.742 & 0.973 & 0.713 & 0.619 & 0.538 & - \\
\hline
\end{tabular}




\subsection{Metering efficiency and percentage sett damage}

Figure 5 presents planting speed against percentage damage, and metering efficiency. The highest mean metering efficiency of $82.19 \%$ was at $2 \mathrm{~km} / \mathrm{h}$ whereas the least of $78.48 \%$ was at $4 \mathrm{~km} / \mathrm{h}$. There were significant differences $(\mathrm{p} \leq 0.05)$ in metering efficiency. The trend depicts that metering efficiency increased with decreasing planter forward speed. The mean metering efficiency of $80.85 \%$ was higher than that of [17] 73\% and less than $98 \%$ for Aluko and Koya [21]. Physical properties of minisett and type of metering mechanism could play a role in the metering efficiency obtained which confirms a report by Awulu et al.[17] that physical properties of sweet potato affect dropping of the planting material due to different size of it. The metering efficiency was negatively correlated with tractor speed $(\mathrm{r}=-$ $0.547)$ and wheel slippage $(r=-0.661)$.

The greatest mean sett damage of $0.918 \%$ occurred at a tractor forward speed of $5 \mathrm{~km} / \mathrm{h}$ while the least of $0.018 \%$ was at $2 \mathrm{~km} / \mathrm{h}$. There were significant differences $(\mathrm{p} \leq 0.05)$ in mean sett damage. Generally, the correlation was positively correlated with the percentage of seed damage with tractor forward speed ( $r=0.862$ ) (Table 2). Similarly, the trend increases as tractor forward speed increasing. The mean percentage of seed damage was lower as against 2.7 and $1.71 \%$ recorded by Awulu et al. [2] and Ani et al. [15], respectively.

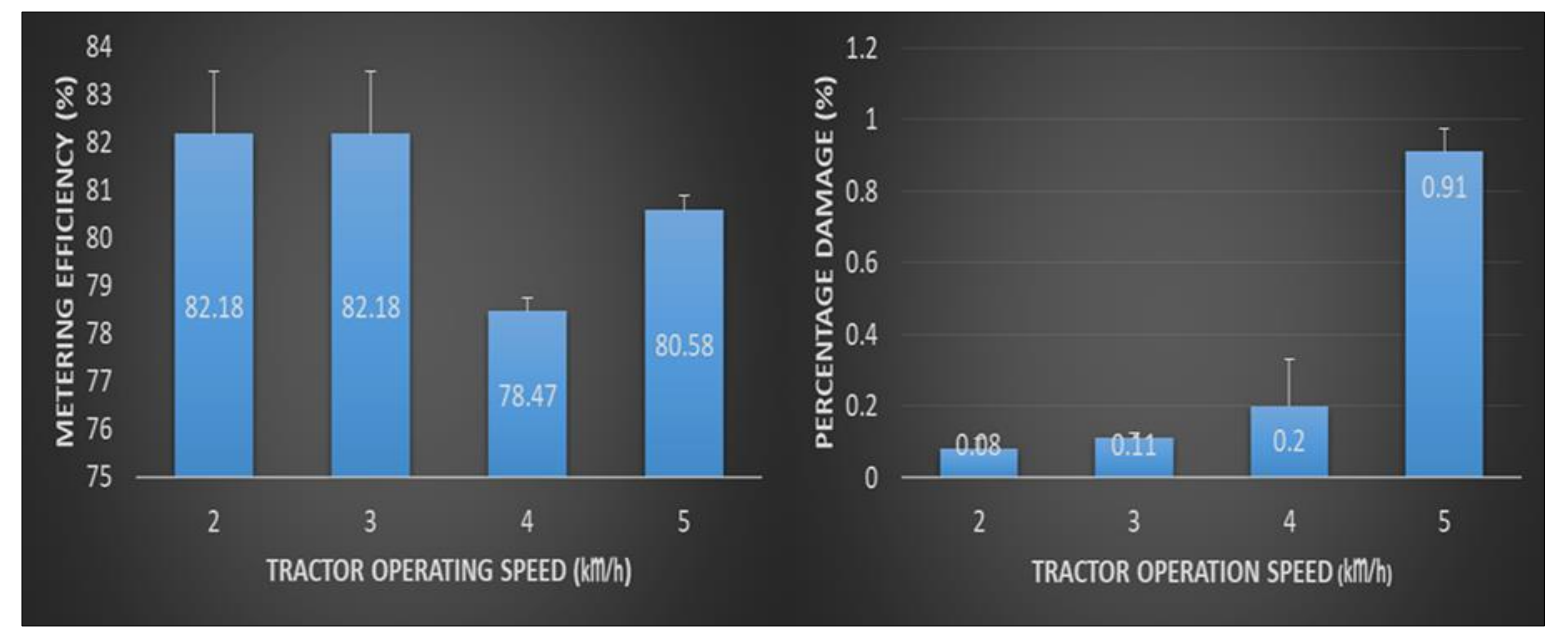

Figure 5 Planting speed, percentage damage, and metering efficiency

\subsection{Theoretical field capacity}

Theoretical field capacity at tractor varying speed was shown in Table 2 . The highest theoretical field capacity of 2.63 $\mathrm{h} / \mathrm{ha}$ was at a tractor forward speed of $5 \mathrm{~km} / \mathrm{h}$ while the least of 2.50 was at $2 \mathrm{~h} / \mathrm{ha}$. There were no significant differences ( $>0.05)$ in theoretical field capacity. A positive correlation was observed between theoretical capacity and tractor forward speed $(\mathrm{r}=0.644)$. The recorded value was higher than $2.46 \mathrm{~h} / \mathrm{ha}$ at $5 \mathrm{~km} / \mathrm{h}$ recorded by [21] but lower than $12.04 \mathrm{~h} / \mathrm{ha}$ recorded by [17] at tractor forward speed of $5.8 \mathrm{~km} / \mathrm{h}$. Yam's characteristics and soil conditions could attribute to the difference in theoretical capacity.

\subsection{Wheel-slip, fuel consumption and speed}

Figure 6 present wheel slip and fuel consumption at tractor varying speed. There were significant differences ( $\mathrm{p} \leq 0.05$ ) in wheel slip at a tractor varying speed (Table 2). The trend indicates that wheel slip increased as tractor forward speed increased. Varying operating speed could play a role in difference in the wheel slip. Again, the highest fuel consumption of $9.62 \mathrm{l} /$ ha was recorded. There were significant $(\mathrm{p} \leq 0.05)$ mean differences in fuel consumed in tractor varying speed. Fuel consumption was positively correlated with tractor forward speed $(r=0.780)$.

Figure 7 presents principal components analysis (PCA) and loading plot to show the correlation between the tractor speed and field evaluated parameters. PCA allows the use of samples and variables which are not measured in the same units (e.g. speed, metering efficiency, field capacity, fuel consumption, wheel slip among others) to be analysed to reveal the relationship and variation among them [23]. The first two factors in the PCA analysis that had eigenvalues $>1$ and contributed $78.8 \%$ of the total variation, were considered. The first principal component that explained $56.9 \%$ of the total variation was tractor operating speed. Metering efficiency was a factor influencing the second principal 
component, which explained $21.9 \%$ of the total variations. The PCA results used correlation to show greater consistency among the parameters and the tractor forward speed. Some correlations exist among varying speeds and parameters.

As shown in Figure 6, Speed, FC, and WS appeared close, which agrees with the findings in the correlation matrix (Table 2). Fuel consumption and wheel slip increase with increasing tractor forward speed. Fuel consumption (FC), wheel slip (WS), percentage damage of sett (PD), Theoretical field capacity (TC), and Field efficiency (FE) are strongly correlated with tractor forward speed. Mostly, parameters that are influenced by speed are strongly correlated with each other and have the same orientation with very small angles between them (e.g. WS, PC, speed, FC). Metering efficiency and evenness of dropping are usually tightly correlated and negatively influence field efficiency, wheel slip, planting capacity, and tractor forward speed with closely $140^{\circ}$ apart.

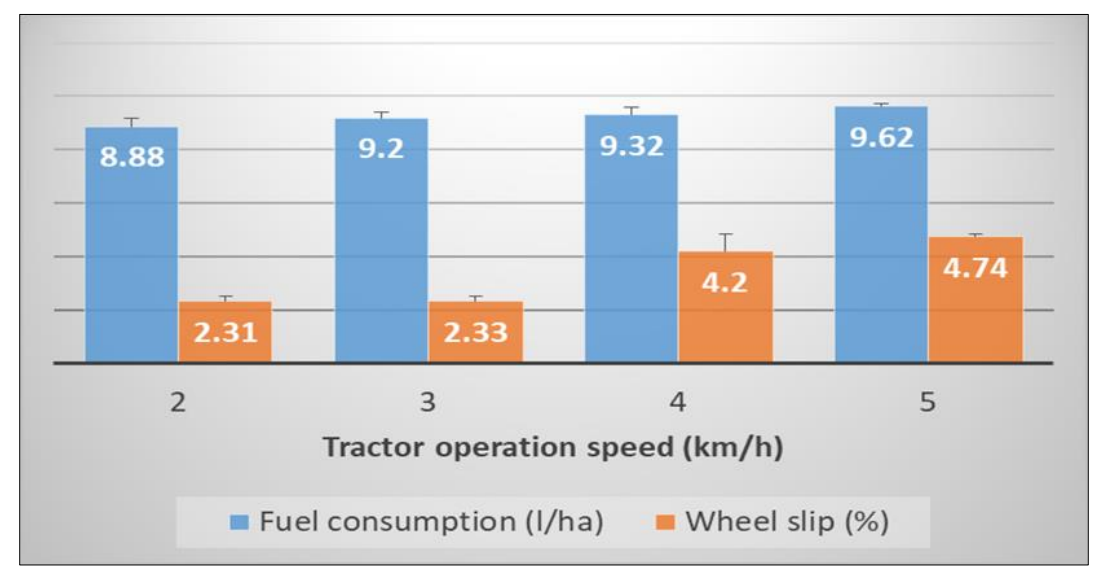

Figure 6 Tractor speed on wheel slip and fuel consumption

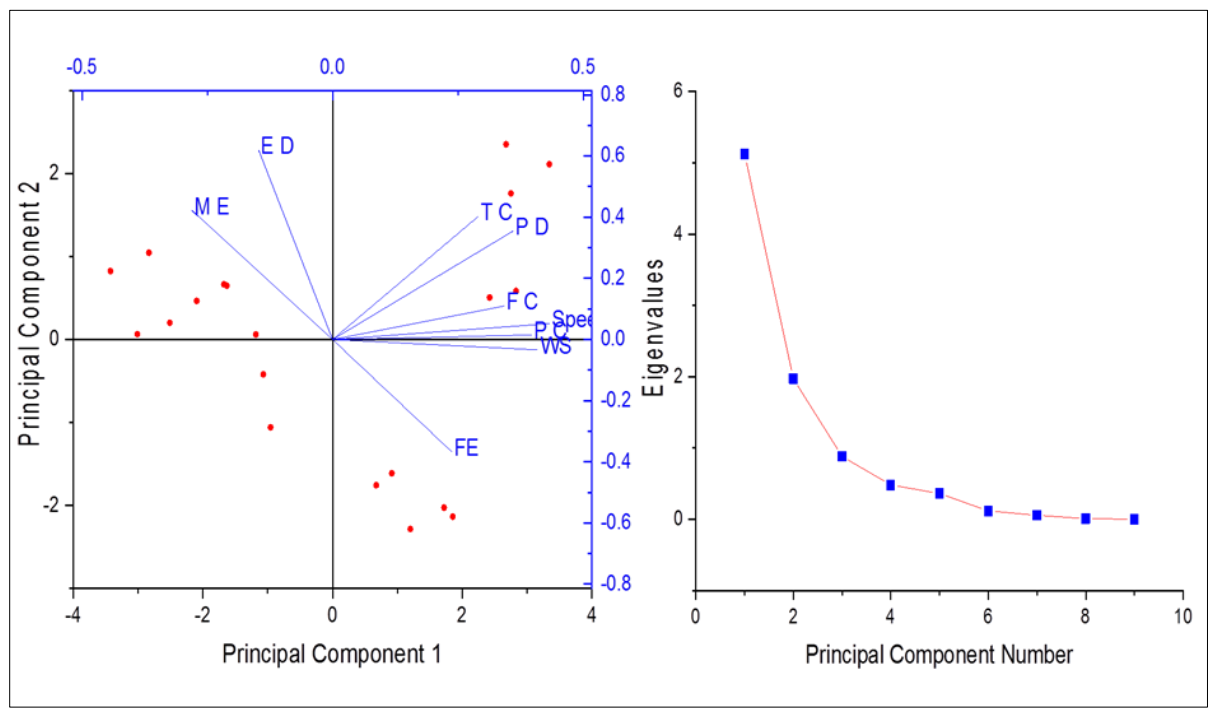

Figure 7 PCA and loading plot of field parameters

\section{Conclusion}

Field performance evaluation of the yam minisett planter revealed that, Planter testing in a soil with moisture content of $7.0-9.5 \%$ and bulky density $1.31-1.64 \mathrm{gm}^{-3}$ produces best fuel consumption of $8.88 \mathrm{l} /$ ha, evenness of dropping (87.0\%), metering efficiency of $87.8 \%$ and planting capacity of 0.26 ha. The planter works safely only at tractor forward speed. Reversing whiles driven wheels touching the ground stand chance of damaging metering mechanism during planter operation. 


\section{Compliance with ethical standards}

\section{Acknowledgments}

The authors wish to express their profound gratitude to Prof. Otto of the CSIR-Crops Research Institute and the entire staff of Takoradi Technical University, Department of Automotive and Refrigeration Engineering.

\section{Disclosure of conflict of interest}

All Authors declare that there is no conflict of interest.

\section{References}

[1] Boydas MG. Effect of cup size, seed characteristics and Angular speed on the performance of an automatic potato planter under laboratory condotion. Journal of agricultural sciences. 2017; 23: 317-327.

[2] Awulu J, Audu J, Nuhu G. Development and Evaluation of Manually Operated Seed Broadcaster. Journal of Agricultural Engineering and Biotechnology. 2014; 2: 13.

[3] Steele JB, Bon TA, Moos JA. Capstone design experiences in the development of a two-row plot scale potato planter. Applied engineering in Agriculture. 2010; 26(1): 173-182.

[4] Pavek MJ, Thornton RE. Poor planter performance: What's it costing the average Washington potatoo grower? In: Proceedings of the 42nd Annual Woshington State potato Conference and Trade Fair, 4-6 February, Moses Lake, Woshington, USA. 2003; 13-21.

[5] Seyedbagheri M. On farm evaluation of potato planter performance. 2019.

[6] Klassen J. Planter performance study. In: Proceedings of the 14th Annual Woshington State potato Conference and Trade Fair, 4-6 February, Moses Lake, Woshington, USA. 1975; 43-47.

[7] Rupp JN, Thornton RE. Seed placement and plant stand- is it worth worrying about? In: Proceedings of the 31st Annual Woshington State potato Conference and Trade Fair, 4-6 February, Moses Lake, Woshington, USA. 1992; 167-181.

[8] Kutzbach HD. Influence of crop properties on the efficiency of Agricultural Machines and equipment. 4th International Conference on physical properties of agricultural materials. Rostock, Germany. 1989; 447-455.

[9] Buitenwerf H, Hoogmoed W, Lerink P, Müller J. Assessment of the Behaviour of Potatoes in a Cup-belt Planter. Biosystems engineering. 2006; 95: 35-41.

[10] Al-Gaadi KA, Marey SA. Effect of forward speed and tuber characteristics on tuber spacing uniformity for a cupbeltpotato planter. Middle-East Journal of Scientific Research. 2011; 8(4): 753-758.

[11] Altuntas E. The Effects of some operational parameters on potato planter's performance. Agricultural Mechanization in Asia, Africa and Latin America. 2005; 36(2): 71-74.

[12] Amponsah SK, Bobobee EY, Agyare WA, Okyere JB, Aveyire J, King SR, Sarkodie-Addo J. Mechanical cassava harvesting as influenced by seedbed preparation and cassava variety. Applied Engineering in Agriculture. 2014; 30(3): 391-403.

[13] De Angelis M. The beginning of history: Value struggles and global capital, Pluto Press. 2007.

[14] Amponsah SK, Berchie JN, Manu-Aduening J, Danquah EO, Adu JO, Agyemang A, Bessah E. Performance of an Inproved manual cassava harvesting tool as influenced by planting position and cassava variety. African Journal of Agricultural Research. 2017; 12(5): 309-319.

[15] Ani O, Uzoejinwa B, Anochili N. Design, construction, and evaluation of a vertical plate maize seed planter for gardens and small holder farmers. Nigerian Journal of Technology. 2016; 35: 647-655.

[16] Rajendran V, Kandhadai AA, Krishnan V. Systems, methods, and apparatus for signal encoding using pitchregularizing and non-pitch-regularizing coding. Google Patents. 2017. 
[17] Awulu J, Itodo I, Umogbai V. Effect of Tractor Forward Speed on Metering Efficiency and Evenness of Planting of a Device for Mechanized Yam Sett Planting. The International Journal of Engineering and Science (IJES). 2013; 2(5): 61-67.

[18] Smith DW, Sims BG, O'Neill DH. Testing and Evaluation of Agricultural Machinery and Equipment: Principles and Practices. Rome, Italy: Food and Agriculture Organization. 1994.

[19] Bosrotsi CK, Addo A, Dzisi KA, Agodzo SK. Technical Performance and Economic Feasibility Assessment of A Mechanical Yam Harvester. International Journal of Research Studies in Agricultural Sciences (IJRSAS). 2017b; 3(3): 1-8.

[20] USDA CP. National Agricultural Statistics Service. Government Printing Office, Washington DC (annual issues, 1965-2002).

[21] Aluko O, Koya O. Development and Preliminary Testing of Metering Equipment for Mechanized Yam Sett Planting. JOURNAL OF AGRICULTURAL ENGINEERING AND TECHNOLOGY (JAET) EDITORIAL BOARD. 2005; 18.

[22] Bamgboye A, Mofolasayo A. Performance evaluation of a two-row okra planter. 2006.

[23] Bobobee EYH. Performance analysis of draught animal-implement system to improve productivity and welfare. 2007. 